À l'intersection des discours de spécialité :

hétérogénéité et unité

\title{
How non-specialist students of English practice informal learning using web 2.0 tools
}

Denyze Toffoli and Geoffrey Sockett

\section{(2) OpenEdition}

\section{Journals}

Electronic version

URL: http://journals.openedition.org/asp/1851

DOI: 10.4000/asp.1851

ISBN: 978-2-8218-0414-2

ISSN: 2108-6354

\section{Publisher}

Groupe d'étude et de recherche en anglais de spécialité

\section{Printed version}

Date of publication: 30 November 2010

Number of pages: 125-144

ISSN: 1246-8185

\section{Electronic reference}

Denyze Toffoli and Geoffrey Sockett, «How non-specialist students of English practice informal

learning using web 2.0 tools », ASp [Online], 58 | 2010, Online since 30 November 2013, connection on 02 November 2020. URL : http://journals.openedition.org/asp/1851 ; DOI : https://doi.org/10.4000/ asp. 1851

This text was automatically generated on 2 November 2020

Tous droits réservés 


\title{
How non-specialist students of English practice informal learning using web 2.0 tools
}

\author{
Denyze Toffoli and Geoffrey Sockett
}

1 Whereas twenty years ago, exposure to English outside the classroom for most French students was often limited to hearing English language songs, the development of web 2.0 interfaces such as blogs, forums and social networks, as well as an increased access to digital media through peer-to-peer networks has led to a significant increase in the potential for exposure to, and interaction with English as it is spoken and written by native speakers and other users. Indeed listening to English language songs on their own has been considered by some (see for example Marquis 2007) to be of little value for language learning, since the lyrics are rarely processed for meaning. In contrast, media such as personal messages or films and TV series (with their inherent narrative structures) seem to be more likely candidates for such processing. The extent to which this potential exposure is a reality for students other than English language majors is a question which needs to be answered in order to correctly tailor language classes to the realities of communicative tasks actually encountered by students outside the classroom. As a University department seeking both to carry out research into informal learning, and to provide language classes for some 1,000 non-specialist students in English, the Department of Applied Linguistics and Language Didactics of the University of Strasbourg (France) undertook a survey of some 250 students to determine to what degree and in what ways they were exposed to English outside the classroom as part of a study into informal aspects of language acquisition. In this article, the theoretical background of informal language learning is reviewed and results from the survey mentioned above are presented and analysed. In the concluding part of the article, pedagogical applications are suggested for both the Strasbourg learning centre context and more broadly that of similar centres in France and in other countries where similar phenomena may be observed. 


\section{What is informal learning?}

2 The idea that learning may take place outside the classroom is certainly not a new one. Jay Cross (2006) argues that

learning is that which enables you to participate successfully in life, at work, and in the groups that matter to you. Informal learning is the unofficial, unscheduled, impromptu way people learn to do their jobs. (2006: 19)

3 This general definition provides a framework for informal learning which associates it with socio-constructivist models of learning (learning is constructed with others), and also sees learning as action in a social environment (learning takes place through and for the execution of meaningful tasks). As such it can be related to task-based pedagogies insofar as exposure to learning material is more than just hearing or reading texts, it can also, in the context of language learning for example, be the meaningful carrying out of tasks with other language users in the target language. As will be suggested in this paper, web 2.0 interfaces provide a fruitful setting for such activities. The argument that many jobs are learned informally, while perhaps less true in purely technical areas, can be borne out in the educational sector in fields such as the learning of specific computer skills, the managing of a department and even many types of teaching techniques which tend not to be taught formally through in-service training courses, but are learned anecdotally from colleagues or from such resources as Internet forums.

\section{What is informal language learning?}

4 Although the above definition of informal learning provides a broad outline of the area of study, it would be useful to suggest a more precise application to the field of language learning. The terms "unofficial, unscheduled and impromptu" provide a reasonable starting point for such a definition. Indeed it is clear from the term "unofficial", that the informal learning of English involves practices which do not take place as part of a lesson, whether during class time or as a homework assignment, and any activity prescribed by a teacher in such a context could not therefore be considered an informal learning activity even if the activity itself were indistinguishable from other activities spontaneously engaged in by the language learner. Hence the definition of informal language learning is partly related to the process of deciding to carry out an activity, a notion which is also found in research into learner autonomy. Much as in work on learning tasks, ${ }^{1}$ it is not necessarily the activity itself which can be defined as informal, but rather the intention which leads to it. The term "unscheduled" is a reminder that even though as Pienemann $(2007: 140)$ points out, language learning often follows a natural order, informal language learning does not take place according to a timetable or progression known to the learner, neither does it take place at fixed times. Finally the "impromptu" aspect of informal language learning can be seen to draw parallels with work on incidental learning (Rieder 2003), in which the learner does not set out to learn and while attention is paid to the material, the learning process is not necessarily a conscious one. A second important aspect of Cross's definition of informal learning is the notion of "participating successfully in life, at work, and in the groups that matter to you." Any definition of informal language learning, in the action-based context of language learning in Europe, should include a 
reference to the aim of participating in social groups with other language users. Again the affordances of web 2.0 interfaces provide a practical outlet for such objectives.

\section{How does informal learning differ from input hypothesis?}

5 Any description of learners relaxing at home watching television in the context of language learning methodology will of course draw comparison with research into natural methodologies in the 1970s and 1980s, and most notably the "input hypothesis " put forward by Stephen Krashen (1978). It would therefore briefly be useful to contrast the informal language learning phenomena presented in this paper and Krashen's models. Input hypothesis suggests that a large quantity of comprehensible listening and reading material is a necessary although insufficient condition for language acquisition, leading eventually to oral expression. Krashen's natural approach (Krashen \& Terrell 1983) suggests that the learning process should consist of a long phase of comprehension activities, the consequence of which will later be an ability to produce the language. Even today, researchers such as Heather Hilton (2005) stress the importance of quantitative input, and the practices we witness through this study may indicate a change in students' extra-curricular experiences of English (at least quantitatively).

Other key features of Krashen's model are the importance of the affective filter, a psychological combination of anxiety, self-image and motivation, and the "monitor model", a system generally informed by formal instruction, which permits the learner to check the grammatical conventionality of his or her productions. Resemblances between informal language learning and these so-called "monitor model" approaches can clearly be seen in the quantity of listening input and the lack of affective pressure experienced by the language user. Web 2.0 interfaces, most notably social networking sites by their very nature, encourage language users to react to written and oral stimuli by making brief written comments, leading to a fairly fluid written interaction between users. This would be quite coherent with the types of writing promoted in the natural approach, as a mnemonic device, a support to oral interaction, a skill with its own functional goals (in our case commenting on others' postings) and a means to practice monitoring. It might seem that in this type of informal language learning, written activities may be replacing those previously only encountered in the language classroom. It would seem to be the case that engaging in what Swain (2005) calls "languaging" (engaging in meaningful interaction in the target language) promotes language acquisition through production as well as comprehension. The processes at work in informal language learning would therefore appear to provide a good example of Swain's "output hypothesis" as well as of a certain "natural approach".

7 Regarding the role of formal learning, Ellis (1994) and others have suggested ways in which explicit knowledge can be brought to bear on the essentially implicit process of language learning. In the case of informal language learning, the role of informal feedback, the use of chunks of native speaker utterances and other forms of scaffolding in written interactions is likely to play as important a role as that of formal instruction, since these phenomena are likely to be more frequent, immediate and contextually relevant than information obtained in a formal learning context, particularly in the case of this study of non-specialist language learners who only study English formally 
for some 48 hours per year. It is therefore possible that the monitor in this learning system is made up largely of language chunks gleaned from personal interaction in social networks and perhaps also language learned from the more repetitive types of downloaded media such as television series in which similar exchanges are repeatedly played out in similar contexts.

\section{What are web 2.0 interfaces?}

8 Use of the Internet in the 1990s and early 2000s often involved reading and sometimes listening to information produced by authors unknown to the non-native language user. This type of static information site might be considered an example of web 1.0. In this study of informal language learning, the term web 2.0 interfaces is used to describe a range of web-based services driven by data bases such as MySQL which allow language users to create and modify the content of a site through WYSIWYG interfaces which require no access to or knowledge of HTML code or file transfer protocols. The most primitive examples of these services, such as forums and webmails have existed for many years, and more recently the use of social networking sites such as Myspace and Facebook have become increasingly important. In 2008 Facebook became the second most visited site on the web, after Google (according to http://www.alexa.com/ topsites). Web 2.0 services can provide synchronous or asynchronous communication between users and can involve written or spoken interaction.

One of the aims of this study is to determine whether non-native speakers of English are more likely to use synchronous services such as chatrooms, instant messenger services and voice over internet protocol (VOIP) services when using English online, or asynchronous services such as blogs, forums and social networks. Linked to this area of inquiry is the question of which language skills are being practiced informally by nonnative speakers of English online and to what extent different online services favour one or the other of the five skills presented in the Common European Framework of Reference for Languages (CEFR 2000).

\section{What is new about peer-to-peer downloading?}

10 Peer-to-peer downloading services such as Bit Torrent or Emule use technologies which enable the (often slow) downloading of digital recordings of audio, but also films copied from DVD or TV series recorded digitally or copied from broadcasters' video on demand services. These downloading practices are illegal, as indeed were the creation of libraries of VHS copies of films and TV series of which they are the descendents. Since the rights to broadcast TV series are granted on a country by country basis, access to the latest episode of a popular show from the United States for example is not available in a country such as France until the dubbed version of that show is made and broadcast, often many months later. The attraction of peer-to-peer sites is therefore not merely the opportunity to avoid paying for a visit to the cinema or a CD or DVD, but also to view shows that will subsequently be broadcast for free before their broadcast date in many countries. The side effect of this phenomenon for language learning is of course that the TV shows in question are usually available only in their original English language version with in some cases closed caption, or other subtitling as an option. 
11 Historically, regarding the issue of subtitling, European countries have fallen into two broad groups, small countries - such as Holland and Sweden - in which the dubbing of series into the local language was considered uneconomical and where shows are therefore broadcast in their original version with local language subtitles, and larger countries - such as France and Germany - in which series are systematically dubbed into the local language. A study in progress by Rupérez-Micola, Banal-Estañol \& Bris (2009), entitled "TV or not TV: subtitling and English skills", demonstrates the superiority in English listening comprehension skills of adolescents in those countries in which subtitling is used. The early availability of English-language series in France is therefore a relatively recent phenomenon. Anecdotal evidence from students suggests that having begun to watch programmes in the original language, they find the dubbed versions, when they later appear, less authentic and less dramatically convincing, and often continue to watch downloaded original language versions of their favourite programmes even when the dubbed versions later appear. It was such anecdotal evidence which led us to set up the study described in the latter part of this article.

\section{Methodology}

12 This study attempts to determine the extent to which non-specialist students of English are actually in contact with this language on a regular basis. Its primary assumption is that the majority of this contact would be via the web. Presented in the following pages are the results of a survey conducted at the University of Strasbourg in November 2009. Our target population consists of students studying two hours of English per week in a language centre for non-specialists. They are all majoring in the humanities (sociology, history, fine arts...) and have a minimal language requirement. Those who are studying English or German come to the Centre de ressources et d'apprentissage des langues (CRAL), where they follow a programme of guided on-line learning and face-to-face workshops.

13 The survey was distributed by teachers at the end of scheduled classes and collected forthwith, explaining undoubtedly the large number of responses received. 222 responses to the questionnaire (of the 250 or so distributed) were collected and analysed. Fourteen statements specifically concern students' habits in English on the Internet that might involve informal language learning. Some sample questions from this part of the survey include: "I read written documents in English on the Internet"; "I participate in a virtual world where I use English"; "I chat online in English with people I have never met in person" (see Appendix 1). Twenty further questions explore students' use of Facebook in particular and was the subject of a communication at the ACEDLE colloquium in December 2009 (Sockett 2010). Some of these questions are also pertinent to this study (see Appendix 2). We did not question participants about their other informal learning activities in English. The statements in the questionnaire are rated on a four-point Likert scale by which respondents indicate their degree of agreement with the statement, or indicate the frequency with which they carry out the activity mentioned in the statement. Where relevant, respondents are also asked to give examples of activities they engage in.

Content validation of the questionnaire took the form of a review process by a team of three researchers experienced in this type of study, in which the relevance of each question was assessed with regard to the research questions. Face validation took the 
form of a trial phase in which the questionnaire was administered to 15 students and feedback on ambiguous questions used to develop the final version.

\section{Results}

The results we present below attest to the regular on-line activity in English of 222 students. Only 6 of the students who responded to the questionnaire claimed to have no regular Internet activities in English.

In this section we will explore the results according to the five language skills of the CEFR: listening, reading, writing, interaction and speaking. While all skills areas could potentially be impacted, we shall see that three appear to be particularly involved in web 2.0 activity: listening, reading and writing, especially written interaction. For each set of results presented we provide a brief discussion of the discursive characteristics of the media students are interacting with. This informs the final section where we discuss possible applications of this information for a classroom setting.

\section{Listening comprehension}

Figure 1. Frequency respondents engage in listening as compared to reading activities

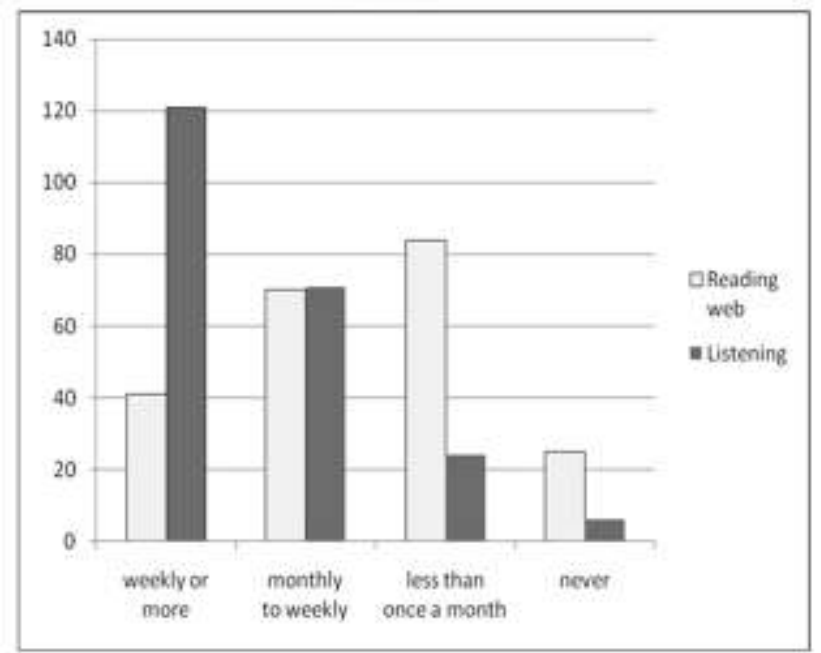

17 Figure 1 compares the frequency with which survey respondents listen to and read English on the Internet. Note that some 90\% (200 of the 222) students surveyed claim to listen to English at least once a month, and that more than half of those questioned listen to English at least once a week. Any traditional view of the Internet as being primarily a source of written information may be undermined by this result, since only some $25 \%$ of respondents claim to read English on the web at least once a week. Indeed the largest group of respondents for this question are occasional Internet users who read documents on the web less than once a month. 
Figure 2. Types of listening

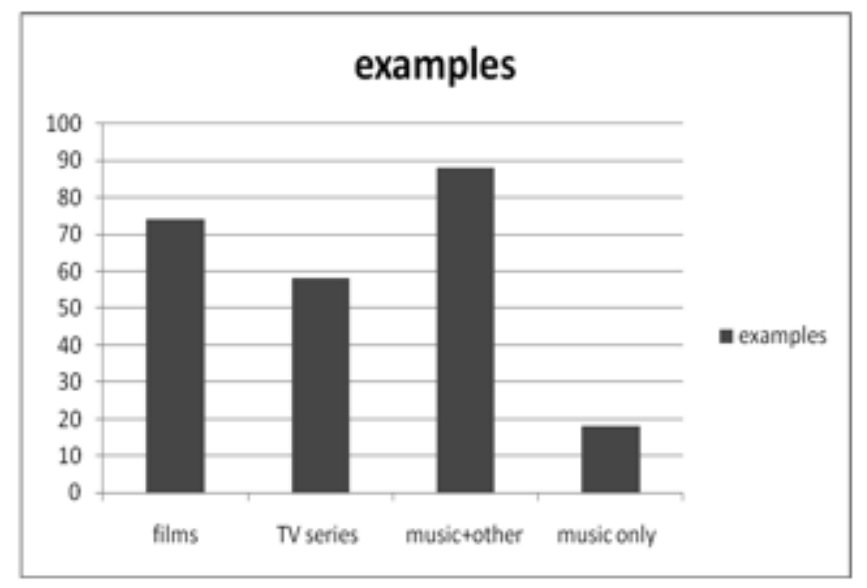

18 Figure 2 seeks to look in more detail at what types of documents respondents are listening to on the web. It has long been the case in France that music with English lyrics has been widely available on radio and television; indeed broadcasting regulators in France allow $60 \%$ of the music played on the radio to be in English. However this has seemingly not led to French teenagers being ranked highly in Europe for listening comprehension (Rupérez-Micola, Banal-Estañol \& Bris 2009). Merely listening to music from a multimedia source rather than on an analogue radio would therefore be unlikely to lead to a significant change in listening comprehension outcomes. The data in figure 2 relate to examples mentioned by respondents, some of whom gave several examples and some of whom gave no examples of listening materials. The answers were grouped in such a way as to make the role of listening to music apparent and to give indications as to the other categories of listening materials.

One finding here is that very few respondents report listening only to music (fewer than $10 \%$ of the sample) and many more indicate that listening to music is only one component of their auditory menu. Twenty-five to thirty percent of respondents report watching English language films and a similar percentage report watching television series in English. Examples of TV series watched by the respondents include Dexter, Kyle XY, The IT Crowd, One Tree Hill, and How I Met your Mother.These programmes all originate from the United States and fall into two broad categories, situation comedies and drama series aimed at a teenage and young adult market.

This data clearly indicate that non-specialist students' informal practices in English represent an increase in the quantity of English heard on a regular basis, thanks to the use of recent un-dubbed and un-subtitled material from peer-to-peer networks. The increases would appear to come not only from numbers of activities (which, as we have seen, occur at least once a week for over half of our sample population), but also the duration of the activities undertaken. A short television series lasts at least 25 minutes and the average film is over 90 minutes long.

21 Moreover, this type of listening input is qualitatively different from other types of listening that French students previously engaged in. The content differs from that of English language songs, which as well as being difficult to grasp on a phonetic level due to issues of rhythm and background noise, also offer few contextual clues as to meaning. It also differs from listening to the news, to "language learner" dialogues, or even listening to "authentic material" and doing tasks that language teachers regularly 
use in the classroom. This is neither skimming nor scanning in terms of listening activity. It is listening undertaken for pleasure (and various sub-groups of pleasure, such as belonging to a certain social group or maintaining a particular self-image). The subject matter is supported by a narrative structure, in a theatrical context where unity of setting and characters dominate, over many episodes or even an entire series.

Discourse characteristics of series tend to involve heavy exposure to contemporary, culturally-coloured dialogue. Audiences tend to be faithful to "their" series, becoming familiar enough with characters and plotlines to be able to successfully predict reactions and outcomes to varying situations. This "faithfulness" could even imply subscribing to the values, beliefs and culture conveyed by the series in question. In the case of films there is obviously potential for a far greater variety of situations, discourses and viewer relationship to the film.

Nonetheless, foreign pre-releases which can provide access to closed caption subtitling for the hard of hearing, but not translated subtitles, would tend also to be a precious resource for students' comprehension, notably in view of recent research by Mitterer \& McQueen (2009), who find that "foreign subtitles help but native-language subtitles harm foreign speech perception."

\section{Reading comprehension}

Figure 3. Types of reading and written interaction

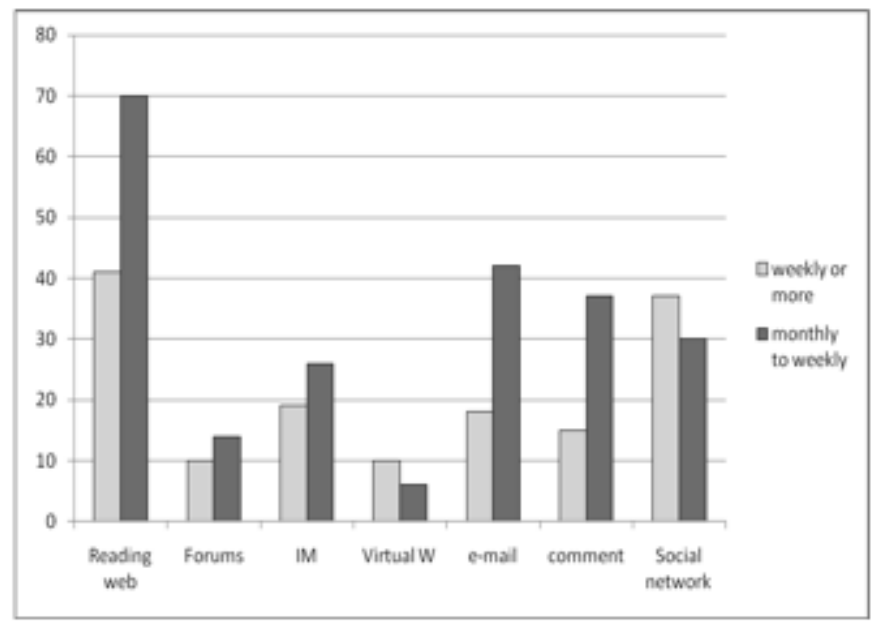

Figure 3 looks in more detail at the contexts in which reading skills are used, and is a reminder that users not only read information on websites, they also interact via other types of text. The most frequent context for reading activities mentioned by the students surveyed is social networking sites such as Facebook and Myspace. Whereas students mostly mention e-mailing in English as an occasional activity, social networking is more often a weekly than a monthly activity. The interactive nature of this reading can be seen in the fact that Facebook users in the survey responded positively to statements such as "I look at messages in English from friends and decide which to comment on" and "Looking at different messages in English helps me imagine what my friends have been doing." 

comprehension activities. The results presented in figure 3 also give some details as to the types of written expression engaged in by survey respondents. Again the statistical dominance of social networking sites such as Facebook can be seen in these results, when compared to potentially context rich interfaces such as virtual worlds, the largest of which, Second Life, rarely has more than 80,000 simultaneous connections. Writing is rarely informative (participating in thematic forums for example) and occurs primarily in contexts where the writer's real name is used (e-mails and social networks) as opposed to those in which the writer's true identity is hidden by a pseudonym or avatar (forums and virtual worlds). Respondents reacted positively to statements such as: "I use English to update my homepage on Facebook" "I write on the walls of friends in English" and "I send messages in English as well as just commenting on what others say".

This type of discourse is generally very short (two sentences or less), personal (takes place on blogs, instant messaging, social networks and e-mail, i.e., direct communication between people who usually know each other personally) and often involves commenting on others' writing (this would be the case for blogs, social networks and forums). An initial observation is that it is specifically this type of writing that the B1 level of the CEFR targets: "Can produce simple connected text on topics which are familiar or of personal interest." It would also appear coherent that our students use more second-order speech acts (answering and reacting), which are more contextually aided, than first-order speech acts (initiating). This is illustrated by the statement: "I adapt expressions my English speaking friends use, then use them myself" to which $73 \%$ of Facebook users responded positively.

As with the results about reading, one of the primary implications that can be reassuring for English teachers is to find that our students are writing, even if it be informal discourse, targeted to both NS and other NNS. We can probably infer that this 
writing practice is useful, as $54 \%$ consider that their "messages in English are getting longer/more complicated".

Finally, we might imagine some access to ESP writing, via Internet forums, but while our results indicate that students use forums, our questions do not allow us to infer whether they actually write in them or primarily read information that they find there without interacting.

\section{Oral expression/Interaction}

31 A final significant finding of this research can be seen in Figure 4 which indicates that in spite of the widespread use of VOIP technologies such as Skype, which provide easy and free access to visioconferencing or voice-conferencing (telephone-type technology), respondents very rarely avail themselves of opportunities for verbal interaction in English on the Internet. Indeed some 70\% of students surveyed say they never use VOIP services in English. Possible reasons for this lack of oral expression will be brought up in the discussion section of this paper.

Figure 4. Frequency of speaking in English via Internet

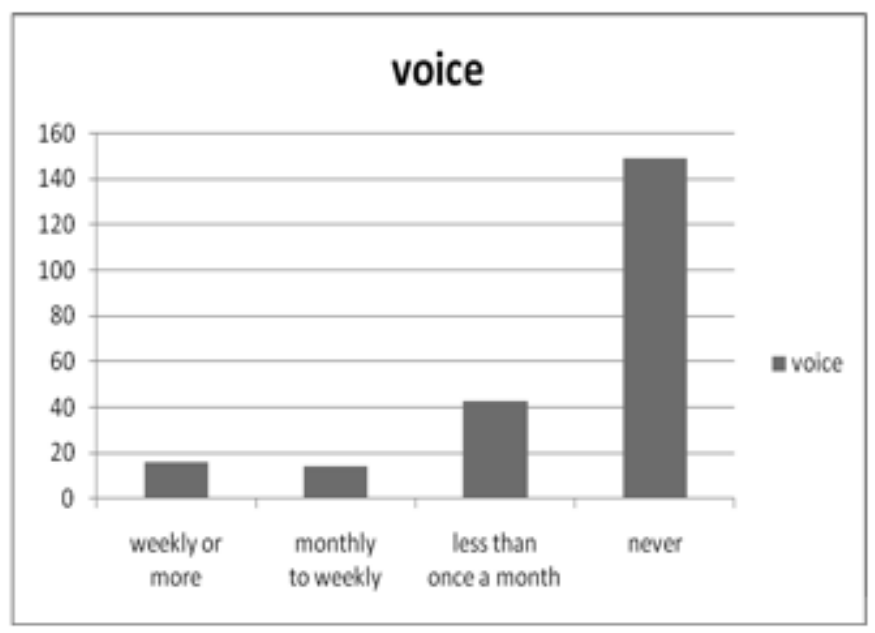

\section{Discussion and pedagogical applications}

The results presented above allow some new insights into students' practice of English, especially concerning listening, reading and written interaction. Below, we suggest some possible pedagogical implications for these results in the language classroom. Obviously if we want informal learning to remain informal, it must remain outside the classroom and even (as suggested in our earlier definition) dissociated from the classroom. However, as language teachers, it is tempting to imagine a possible reinforcement of classroom learning outside or possible integration of advantages from informal learning into more formal learning situations. The suggestions made here should be seen as general guidelines, the specific applications of which are best left to the creativity and sensitivity of the individual classroom teacher.

It would seem that a first and obvious integration of this information involves validating and encouraging this type of informal language learning in our students. It 
means developing an interest in their extracurricular activities and perhaps educating ourselves as to what our students find interesting and worthwhile. The English teachers and researchers participating in the 2010 GERAS conference easily identified images of Samuel Beckett, William Wilberforce, Charlotte Brontë, Nabokov's Lolita and (of course) Shakespeare, who are all on the CAPES or Agrégation programmes of the year. Few of the participants recognised the characters of the favourite television series that students of disciplines other than English actually watch in English (How I Met your Mother, The IT Crowd, etc. mentioned earlier). To what extent does learner-centredness involve actually knowing something about these types of content areas?

Could an effective teacher interface with student content involve activities such as strategy training, that is to say, teaching learners how their own listening of this type of content could be made more operational? Students might share strategies they use with each other; teachers might present strategies that they may be less familiar with (such as predicting, selective attention, self-monitoring, inductive \& deductive inferencing, etc.) and have students test them out on their own to see if they have positive impact on their leisure activities. Integrating student interests could potentially go as far as having them set the listening agenda, either by bringing in extracts of their favourite programme (an episode that was particularly interesting/ surprising/difficult) or perhaps by setting project work around a particularly popular series.

Having seen that reading and writing tend to function as an inseparable pair in informal language learning on-line, teachers could also capitalise on this "natural" propensity for written interaction. This could either be done in distance learning, with twinning classes using blogs or instant messaging, or even done in the classroom, as an occasional alternative to oral pairwork. Other possibilities might include using examples of writing from blogs and forums as teaching tools. These could provide appropriate and easy access to samples of informal language or certain areas of ESP (computer-related forums being an obvious target). We would of course discourage teachers from using samples from instant messaging, social networks or e-mail as these tend to be highly personal and could imply invasion-of-privacy issues.

However, by a slightly different token, we could invite students to practice legitimate peripheral participation (Lave \& Wenger 1991) or perhaps facilitate such participation by having student users of these different technologies teach non-users how to get involved.

\section{Conclusion}

This research into the informal learning of English online suggests that learners of English in France are today exposed to and interacting with authentic English documents in a way which was not possible only a decade ago.

Among the questions raised by these observations, the question of the likely lifespan of such behaviour is a significant one since it will influence the extent to which language teachers might see the need to factor these phenomena into their classroom approaches. It is indeed possible that Social Networks will prove to be a temporary phenomenon similar to the development and subsequent stagnation of interfaces like Friends Reunited or indeed Second Life. Since our results suggest that much of the interaction respondents were involved in concerned actual friends rather than avatars, 
and current relationships and activities rather than past ones, there is some scope to be optimistic that online interaction in English between learners and friends with whom they share English as a common language may be a durable phenomenon, whether on social networking platforms or in another form.

The future of peer-to-peer downloading, streaming, and other practices which expose learners to media output in English seems to be a far more legislative question. These practices are currently tolerated to diverse degrees in different parts of the world, and just as technologies allowing file sharing have become widespread, protection systems such as DRMs (digital rights management systems) could equally gain in sophistication and effectiveness.

From a learner point of view, there is anecdotal evidence that beginning to watch favourite films and television series in English can represent a crossing of the Rubicon, after which viewing dubbed material is no longer a satisfying experience. If borne out by research, this tendency may lead to a durable reduction in the divide which has up to now separated countries in which subtitling is the norm and those in which foreign language material is usually dubbed.

41 From the point of view of language identity, the fact that learners are interacting with others in English opens up a number of avenues for research. While it is clear for example that most interaction take place in a written form even when audio links are available, we do not yet know whether learners choose this mode to increase thinking time in interactions and to hide any pronunciation difficulties they may have in oral communication, or whether they are simply replicating the habits of a generation more used to texting than to calling on the telephone even when the initial cost motivation behind such a choice is beginning to recede. Issues such as loss of face due to errors in text versus audio formats would be a possible example of further research in this field.

42 Further study could also investigate the extent to which the areas of social networking and peer-to-peer downloading overlap. Language users certainly discover English language television series based on the recommendation of friends, many of whom they interact with online, although whether or not these interactions often take place in English is not clear. Beyond the technical affordances of sites such as Facebook to integrate video sources into user contributions, it might be useful to determine to what extent series plot-lines are discussed informally online by non native speakers, and indeed whether they ever engage in more extensive series based language work such as fan fiction, in which fans of series write scripts for new imaginary episodes or as preludes or postscripts to existing episodes.

43 Among the problems facing researchers in the area of informal learning, the very personal nature of the interactions involved brings with it practical and ethical challenges. It is quite natural for learners to be unwilling to open up private exchanges to the scrutiny of research, even with the pretext of only being interested in the linguistic aspects of such communications. Indeed social networking sites allow users to restrict the ways in which people not identified as friends access such conversations. From a pedagogical point of view it would not therefore be advisable to engage in formal practice of such exchanges which are by their very nature private. It is more likely that participation in thematic forums or commenting on thematic blogs might represent a better way of formally practicing similar skills in a less personal context. the field of informal learning is not trapped in an "input hypothesis" (Krashen 1978) 
paradigm, although students are getting lots of input, which could be seen as one way of ensuring that the necessary quantities recommended by researchers such as Hilton (2005) can be attained, especially in listening. They are however not producing similar kinds of language in similar amounts as Swain's output hypothesis (2005) might require. In any case, more research is called for into the longitudinal effects of this kind of informal English exposure.

The old divide between subtitled countries and dubbed countries may be eroding, and assumptions about a lack of contact with and enthusiasm for interaction in English may be in a similar state of flux. Our definitions of words like "texts" and "culture" may not be helping us to be learner-centred so a willingness to accept learner definitions of these terms (including often seemingly banal exchanges and shallow commercial media productions) might be a helpful step towards taking on board the learner's perspective on English.

\section{BIBLIOGRAPHY}

Cross, James. 2006. Informal Learning. San Francisco: Pfeiffer.

Common European Framework of Reference. 2000. Language Policy Division, Council of Europe, Strasbourg. Cambridge: CUP.

Ellis, Nick. 1994. "Introduction: implicit and explicit language learning - an overview". In Ellis, Nick (ed.). Implicit and explicit learning of languages. London Academic Press, 1-31.

Ellis, Rod. 2003. Task-based Language Learning and Teaching. Oxford: OUP.

Hilton, Heather. 2005. “Théories d'apprentissage en didactique des langues". Les langues modernes 2005-3, 12-15.

Krashen, Stephen. 1978. "Relating theory and practice in adult second language acquisition". SPEAQ Journal 2: 9-32.

Krashen, Stephen \& Tracy Terrell. 1983. The Natural Approach: Language learning in the classroom. Hayward, CA: Alemany Press.

Lave, Jean \& Étienne Wenger. 1991. Situated Learning: Legitimate peripheral participation. Cambridge: CUP.

Marquis, Annick. 2007. Les acquis des élèves en anglais et en allemand en fin d'école en 2004 et les contextes favorables à ces apprentissages. Ministère de l'Éducation Nationale : Direction de l'évaluation, de la prospective et de la performance, dossier $n^{\circ} 187$.

Mitterer Holger \& James M. McQueen. 2009. “Foreign subtitles help but native-language subtitles harm foreign speech perception". PLoS ONE 4(11): e7785. <http://www.plosone.org/article/ info:doi/10.1371/journal.pone.0007785> consulted June 11, 2010.

Pienemann, Manfred. 2007. "Processability Theory". In Van Patten, B. \& J. Williams, Theories in Second Language Acquisition. Mahwah, NJ: Laurence Erlbaum Associates, 137-154. 
Rieder, Angelika. 2003. "Implicit and explicit learning in incidental vocabulary acquisition". VIEWS 12-2. University of Vienna. Visible online at: <http://www.univie.ac.at/Anglistik/views/ 03_2/RIE_SGLE.PDF>.

Rupérez Micola, Augosto, Albert Banal-Estañol \& Arturo Bris. 2009. “TV or not TV: subtitling and English skills”. Economics working papers $n^{\circ} 1156$. Universitat Pompeu Fabra.

Sockett, Geoffrey. 2010. "Les processus cognitifs de résolution de problèmes pour l'apprentissage des langues dans des environnements multimedia : Apprentissage informel et réseaux sociaux". Actes du colloque Acedle 2009.

Swain, Merrill. 2005. "The output hypothesis, theory and research", in Hinkel, E. Handbook of research in second language teaching and learning. Mahwah, NJ: Erlbaum. 471-482.

\section{APPENDIXES}

\section{Appendix 1}

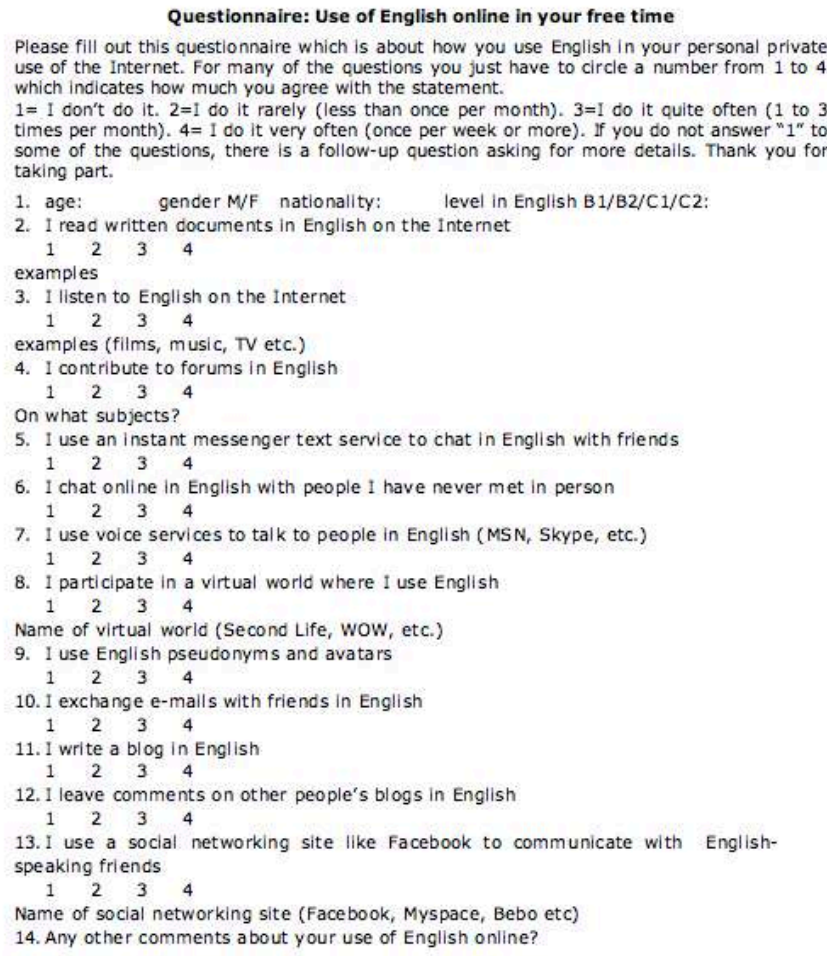

\section{Appendix 2}


Questionnaire: Facebook, and other social network users If you answered question 13 (about Facebook) positively ( 3 or 4 points), please look at
the following questions and circle the number which best corresponds to what you think. If you use a social network other than Facebook, please try to answer the questions

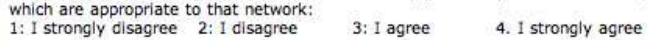

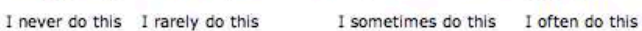

200000160000005400000054315ECEA5.pctImage

200000160000005400000054 C5BBFEDA.pct

\section{NOTES}

1. Ellis (2003) remarks that tasks and exercises are often only distinguishable by the way they are put into practice in the classroom.

\section{ABSTRACTS}

As Internet technologies evolve, learners of English have more informal opportunities to listen to spoken English and interact with English speakers. This article reports on a study carried out at the University of Strasbourg into the informal contacts students have with English on the Internet. The participants in the study are not English majors, but take some English classes as the language requirement of their degrees in other fields. The results of the study show that a great deal of English is listened to in the form of peer-to-peer downloads of English language films and television series. Interaction with other users of English also takes place, primarily on social networking websites, but also in other web 2.0 interfaces. The report concludes with suggestions of pedagogical applications of these new experiences for language learners.

Avec l'évolution des technologies Internet, les apprenants en anglais ont davantage d'occasions informelles d'écouter de l'anglais parlé et d'interagir avec d'autres locuteurs natifs et non-natifs. 
Cet article présente une étude menée à l'Université de Strasbourg sur la manière dont des étudiants sont exposés à l'anglais sur Internet. Les étudiants ne sont pas des étudiants en langues, mais ils doivent apprendre l'anglais dans le cadre de leurs études (secteur LANSAD). Les résultats de l'étude indiquent que les apprenants téléchargent souvent des films et des séries télévisées en langue anglaise. Les interactions avec d'autres utilisateurs de l'anglais ont lieu essentiellement sur des sites de réseautage social mais aussi dans d'autres interfaces web 2.0. L'article se termine par des suggestions d'applications pédagogiques de ces expériences nouvelles pour l'apprenant en anglais.

\section{INDEX}

Mots-clés: apprentissage (informel), hypothèse de l'input, hypothèse de l'output, secteur LANSAD, web 2.0

Keywords: learning (informal), non-specialist students, output hypothesis, web 2.0

\section{AUTHORS}

\section{DENYZE TOFFOLI}

Denyze Toffoli is a member of the language didactics team of the LILPA research unit (EA 1339) at the University of Strasbourg. She teaches in the fields of psycholinguistics, project management, evaluation and online language learning. Her research interests include the above areas and relate particularly to motivation in language learning. dtoffoli@unistra.fr

\section{GEOFFREY SOCKETT}

Geoffrey Sockett is a member of the language didactics team of the LILPA research unit (EA 1339) at the University of Strasbourg. He teaches in the fields of psycholinguistics task-based approaches to language learning and online language learning. His research interests include the above areas and relate particularly to informal learning. gsockett@unistra.fr 